\title{
The Effects of Organization Context, Investment Strategy, and Entry Mode on Management Performance: An Analysis of Taiwanese Enterprises in China Mainland
}

\author{
Shin-Tien Chen \\ Ming Chi University of Technology, New Taipei City, Taiwan
}

\begin{abstract}
Among the top 1,000 Taiwanese enterprises in China listed by the database of Commercial Times in 2012, 763 of them witnessed revenue growth and 864 of them were in profits. This paper seeks to identify the reasons behind such a stellar performance by conducting an empirical study on the top 500 Taiwanese businesses in the database. The results suggest that: (1) the larger the investment into China, the better the business performances; (2) the higher the ownership by Taiwanese firms for the outward investments to China, the better the business performances; (3) compared to investments in IT, technology and machinery, the outward investments from Taiwan to China achieve better returns in commodity, energy, and mining; (4) compared to investments in Eastern, Central, and Western China, the investments in Chinese municipalities generate better returns.
\end{abstract}

Keywords: organizational structure, organizational context, Taiwanese enterprises, management performances

\section{Introduction}

Among the top 1,000 Taiwanese enterprises in China listed by Commercial Times in 2012, 763 of them saw top line growth and 864 of them posted profits. It seems that Taiwanese outward investments to China all paid off. Was that really the case? According to the report on the business environment in China by the Investment Commission, Ministry of Economic Affairs published in 2010, China has been experiencing problems such as gradual decline in exports, sluggish domestic demand, lowering foreign investments, and increase in unemployment. Meanwhile, China is no longer offering incentives to foreign investors (Vanhonacker, 1997). All the factors have hurt the profitability of Taiwanese enterprises in China. In fact, more than $30 \%$ of the Taiwanese investments in China suffered losses. The biggest deficits were seen in the pharmaceutical manufacturing industry, followed by the chemicals manufacturing industry. In other words, outward investments from Taiwan to China are not a sure win.

Taiwanese enterprises have been stepping up their investments into China, evidenced by the increase in investment projects and sizes. There have been wide discussions on this phenomenon. Interestingly, there are no consistent conclusions regarding the key success factors for Taiwanese enterprises in China (Yeung \& Tung, 1996), for example, Gao (1994) believed that investment sizes, employee numbers, factory areas and history,

Shin-Tien Chen, professor, Department of Business Management, Ming Chi University of Technology, New Taipei City, Taiwan.

Correspondence concerning this article should be addressed to Shin-Tien Chen, 84 Gungjuan Rd., Taishan Dist. New Taipei City 24301, Taiwan. E-mail: cst@mail.mcut.edu.tw. 
cost reduction capability, sales, and industry sectors are the key success factors. Lin and Lee (1997) argued that investment sizes, industry sectors, employee numbers, business environments, laws, and regulations have significant effects on the short- and long-term profits of Taiwanese enterprises in China. Therefore, this paper seeks to identify the key success factors, from the management and operations perspectives, for Taiwanese investments in China by sampling the top 1,000 Taiwanese enterprises in China in the 2012 Commercial Times' survey.

\section{Literature Review and Hypotheses}

\section{Organizational Size and Management Performances}

There are a wide range of issues concerning organizational size (Lawrence, 2004; Yan, Zhao, \& Baron, 2007). Banz (1981) sampled the companies listed on the New York ownership exchange in 1936-1975 in order to explore the relationship between firm sizes and management performances. The results suggest that the larger the firms, the better the top line performances. Meanwhile, Cochran (1981) found that large firms post better profitability than SMEs (small-and-medium enterprises). Robbins and Pearce (1992) posited that the firm size is a negative factor to the performance of SMEs. The top 1,000 Taiwanese enterprises in China listed in the Common Wealth Magazine's 2010 survey all see growth in top line and bottom line year over year. Hence, this paper develops $\mathrm{H} 1$ as follows:

H1: The larger the organizational size of the Taiwanese enterprise investing in China is, the greater the management performances will be.

\section{Organizational Age and Management Performances}

The longer the history of overseas investment is, the lower the operating costs and the higher the firm profits will be (Jefferies, 2002). Some studies indicate that the longer the operating history in foreign countries, the easier it is to establish good local relationships and the more incentives it is likely to attract (Beamish, 1993). Kao (1994a) indicated that organizational age is a positive contributor to profits of Taiwanese enterprises. Kao and $\mathrm{Wu}$ (1998) concluded that the longer the operating history is, the more likely it is for Taiwanese enterprises to generate profits in China. Hence, this paper develops $\mathrm{H} 2$ as follows:

$\mathrm{H} 2$ : The longer the operating history of the Taiwanese enterprise investing in China is, the greater the management performances will be.

\section{Ownership Percentages and Management Performances}

High equity holdings may also contribute to the economy of sizes and hence boost profits for Taiwanese enterprises investing in China (Kao \& Chen, 1998). Meanwhile, Kao (1994b) examined the equity ownership of the top 500 Taiwanese enterprises in China in terms of profitability, according to the statistics from the Investment Commission, Ministry of Economic Affairs. The results show that 55.6\% of the Taiwanese investments in China are sole ownership, $21.5 \%$ joint ventures, and $22.9 \%$ others. This suggests that sole ownership is a positive factor to the profitability of Taiwanese enterprises operating in China. Based on the aforesaid argument, this paper develops $\mathrm{H} 3$ as follows:

H3: The higher the ownership percentages for the investment from Taiwanese enterprises in China are, the greater the management performances will be.

\section{Industry Sectors and Management Performances}

China has a large population and understandably its domestic demand represents a big market. There are 
considerable business opportunities in infrastructure and domestic demand (Thompson \& Strickland, 1998). In fact, China boasts rich mining resources and this helps to promote the deployment of infrastructure and the demand of the domestic market. This paper posits that the investments in commodities, energy, or mining related industries can generate higher returns and hence develops $\mathrm{H} 4$ as follows:

H4: Compared to investments other industries, the investments in commodity, energy, and mining sectors in China create stronger management performances for Taiwanese enterprises.

\section{Investment Locations and Management Performances}

Many scholars examine the selection of locations for foreign investors in China (Zhao \& Zhu, 2000; Zhou, Delios, \& Yang, 2002; Chang \& Park, 2005; Nachum \& Wymbs, 2005). Kogut (1991) indicated that the choice of locations in China has significant influence on the financial performances of parent companies in Taiwan. Yigang and Peter (1999) believed that the choice of locations has significant influence on the management performances of the companies investing in China. Schroath, Hu, and Chen (1993) indicated that the majority of Hong Kong investors prefer coastal cities and provinces in China, particularly Guangdong Province. According to the statistics from Commercial Time in 2005, the highest percentage of Taiwan's outward investments in China goes to the eastern and coastal areas, possibly because the infrastructure and the economy are better developed than inland China. In fact, the production costs in coastal regions are lower due to industry clustering effects. Hence, this paper develops $\mathrm{H} 5$ as follows:

H5: Compared to investments in municipalities, central and western China, the investments in eastern China create greater management performances for Taiwanese enterprises.

\section{Entry Modes and Management Performances}

Entry modes refer to the strategies in overseas investments, subject to factors, such as local economies, laws, politics, and cultures (Dunning, 1988; Robbins \& Pearce, 1992; Hans \& Tallman, 1997; Delios \& Beamish, 1999). The majority of Taiwanese enterprises invest in China via holding shells or trading companies in the third territories or countries, mostly likely tax heavens, such as Hong Kong, Singapore, or British Virgin Islands. According to data from Taiwan ownership exchange, the entry model via shells in the third territories or locations for outward investments to China results in better profits for Taiwanese enterprises than other entry modes. Hence, this paper develops $\mathrm{H} 6$ as follows:

H6: Compared to direct investments in China, the investments via shells in the third locations to China create greater management performances for Taiwanese enterprises.

\section{Methodology}

\section{Variable Measurements}

Dependent variable: Management performances. This paper samples Taiwanese enterprises in China and refers to revenues as a proxy for management performances due to the difficulty in data collections.

Independent variables. Table 1 summarizes the operational definitions of independent variables in this paper.

\section{Sampling and Analytical Tools}

This paper samples the secondary data of the first half of the top 1,000 Taiwanese enterprises in China listed by Commercial Times in 2012. This list was the results of extensive visits and investigations for more than 10 months across the Taiwan Strait by China Credit Information Service under the commissioning of 
Commercial Times. The rankings of over 10,000 Taiwanese companies active in China were based on revenues. The finalized list was based on the sampling of 5,000 Taiwanese enterprises in China with annual revenue of 25 million yuans (RMB) and above. A total of nine financial metrics were used as assessment indicators: net revenues, net revenue growth, pre-tax earnings, pre-tax margin, shareholders' equity, equity ratios, total assets, returns on assets, and revenue per employee.

Table 1

Definitions of Independent Variables

\begin{tabular}{|c|c|}
\hline Variables & Definition \\
\hline \multicolumn{2}{|c|}{ Organizational context } \\
\hline Organizational age & Number of years of the Taiwanese enterprise's investment in China. \\
\hline Organizational size & $\begin{array}{l}\text { Measured with the number of employees based on the } 2007 \text { data from Commercial Times regarding top } \\
1,000 \text { Taiwanese enterprises. Use of natural logarithm due to large variances in these numbers. }\end{array}$ \\
\hline \multicolumn{2}{|l|}{ Investment strategy } \\
\hline Investment location & (1) Municipalities; (2) Eastern China; (3) Central and Western China. \\
\hline Ownership & Dummy variable of 1 if $100 \%$ and 0 if not. \\
\hline Industry sector & $\begin{array}{l}\text { (1) IT, electronics, and machinery; } \\
\text { (2) Traditional manufacturing; } \\
\text { (3) Commodity, energy, and mining; } \\
\text { (4) Steel and automobiles; } \\
\text { (5) Consumer goods. }\end{array}$ \\
\hline \multicolumn{2}{|l|}{ Entry mode } \\
\hline Entry mode & $\begin{array}{l}\text { (1) Remittances from the third locations into China; } \\
\text { (2) Via shells in the third locations to investment in China; } \\
\text { (3) Via existing companies in the third locations; } \\
\text { (4) Direct investments in China; } \\
\text { (5) Other methods. }\end{array}$ \\
\hline
\end{tabular}

\section{Analysis and Discussion}

\section{Descriptive Statistics of Variables}

Table 2 summarizes the frequency distribution of the sample characteristics of 503 Taiwanese enterprises in China from the top 1,000 list. Table 3 lists the means, standard deviations, and Pearson coefficients of individual variables.

\section{Organizational Contexts and Management Performances}

Organizational size. According to Model 1 in Table 4, organization sizes have significant and positive influence over management performances of Taiwanese enterprises investing in China $(\beta=0.547, p<0.01)$, supporting H1. In fact, it seems that the greater the size is, the better the performances will be. In the early days, Taiwanese enterprises went to set up factories in China to take advantage of the cheap and ample labor. Virtually all of the Taiwanese companies went to China were operating in the labor intensive manufacturing industries. The growing size of operations in China eventually helps to prove operating results due to economies of size.

Organizational age. According to Model 1 in Table 4, organizational age has a significant and negative effect on management performances $(\beta=-0.018, p<0.1)$ and this result does not support $\mathrm{H} 2$. This paper examines the sample and finds that the year of 1990 is an important watershed for the Taiwanese enterprises investing in China. Before 1990, Taiwanese enterprises were confronted with extensive restrictions from the government on their investments in China. As a result, the majority of early investments were in the consumer 
goods industries with low entry barriers in technology and capital. However, low entry barriers also mean intensified competition. It was hardly surprising that fierce competition undermined management performances or even caused failures for Taiwanese enterprises in China.

Table 2

Frequency Distribution of Sample Characteristics

\begin{tabular}{llrr}
\hline & Characteristic & Count & $\%$ \\
\hline \multirow{4}{*}{ Industry sector } & IT, electronics, and machinery & 308 & 61.2 \\
& Traditional manufacturing & 96 & 19.1 \\
& Commodity, energy, and mining & 38 & 7.6 \\
& Steel and automobiles & 37 & 7.4 \\
& Plastic processing & 24 & 4.8 \\
\hline \multirow{3}{*}{ Investment location } & Municipalities & 83 & 16.5 \\
& Eastern China & 399 & 79.3 \\
& Central and Western China & 21 & 4.2 \\
\hline \multirow{3}{*}{ Entry mode } & Remittances from the third locations into China & 34 & 6.8 \\
& Via shells in the third locations to investment in China & 328 & 65.2 \\
& Via existing companies in the third locations & 127 & 25.2 \\
& Direct investments in China & 4 & 0.8 \\
& Other methods & 10 & 2.0 \\
\hline \multirow{2}{*}{ Ownership } & 100\% ownership & 244 & 48.5 \\
\hline
\end{tabular}

Note. $N=503$

Table 3

Means, Standard Deviations, and Pearson Coefficients of Individual Variables

\begin{tabular}{lcccccc}
\hline & Mean & Standard deviations & 1 & 2 & 3 & 4 \\
\hline 1. Revenue & 12.888 & 1.220 & - & & & \\
2. Organization size & 6.577 & 1.299 & $0.580^{* * *}$ & - & & \\
3. Organizational age & 9.268 & 4.208 & -0.040 & 0.040 & - & - \\
4. Ownership & 15.297 & 32.365 & $-0.529 * * *$ & $-0.305^{* * *}$ & $-0.103^{*}$ & - \\
\hline
\end{tabular}

Notes. $N=503 ; * p<0.1 ; * * p<0.05 ;$ and $* * * p<0.01$.

\section{Investment Strategies and Management Performances}

Ownership. The analysis in Table 4 indicates that ownership has significant and positive influence on management performances $(\beta=0.500, p<0.01)$, supporting H3. Taiwanese enterprises are better informed about the investment environment in China. Meanwhile, the positive factors, such as China's entry into the World Trade Organization and gradual reductions in import tariffs, have prompted Taiwanese companies to invest in China in the form of sole ownership. The 100\% ownership of subsidiaries means complete control over capital utilization and strategic implementations. This approach is conducive to strong operating results in the highly competitive Chinese market. According to statistics from Commercial Times, only nine out of the top 50 Taiwanese enterprises in China in 2005 operated as joint ventures. All the other 41 out of the top 50 Taiwanese enterprises in China operated as sole ownership. It is worth noting that almost all the better performers operated in China as sole ownership. Put differently, the higher the equity stake is, the stronger the management performances will be. This may be the reason why ownership exhibits a significant and positive impact on the management performances of Taiwanese enterprises in China. 
Table 4

Hierarchical Regression Analysis

\begin{tabular}{|c|c|c|c|}
\hline Dependent variable & Model 1 & Model 2 & Model 3 \\
\hline \multicolumn{4}{|l|}{ Organizational context } \\
\hline Organizational size & $0.547 * * *$ & $0.543 * * *$ & $0.543 * * *$ \\
\hline Organizational age & $-0.018 *$ & -0.130 & -0.120 \\
\hline \multicolumn{4}{|l|}{ Investment strategy } \\
\hline Ownership \% & & $0.500 * * *$ & $-0.503 * * *$ \\
\hline \multicolumn{4}{|l|}{ Industry sector } \\
\hline IT, electronics, and machinery & & $-0.728 * * *$ & $-0.776 * * *$ \\
\hline Traditional manufacturing & & $-1.061 * * *$ & $-1.071 * * *$ \\
\hline Commodity, energy, and mining & & (Reference group) & (Reference group) \\
\hline Steel and automobiles & & $-0.567 * * *$ & $-0.632 *$ \\
\hline Plastic processing & & $-0.643 * *$ & $-0.705^{* *}$ \\
\hline \multicolumn{4}{|l|}{ Investment location } \\
\hline Municipalities & & $0.347 * *$ & $0.336 * *$ \\
\hline Eastern China & & (Reference group) & (Reference group) \\
\hline Central and Western China & & -0.146 & -0.101 \\
\hline \multicolumn{4}{|l|}{ Entry mode } \\
\hline Remittances from the third locations into China & & & -0.269 \\
\hline Via shells in the third locations to investment in China & & & (Reference group) \\
\hline Via existing companies in the third locations & & & -0.013 \\
\hline Direct investments in China & & & -0.786 \\
\hline Other methods & & & 0.085 \\
\hline
\end{tabular}

Notes. $N=503 ; * p<0.1 ; * * p<0.05 ;$ and $* * * p<0.01$.

Industry sector. According to Model 2 in Table 4, the management performances are the best in the commodity, energy, and mining sectors, followed by steel and automobiles $(\beta=-0.632, p<0.01)$, plastic processing $(\beta=-0.705, p<0.05)$, IT, electronics, and machinery $(\beta=-0.776, p<0.01)$, and traditional manufacturing $(\beta=-1.071, p<0.01)$. This result supports $\mathrm{H} 4$. The domestic demand in China for consumer products and industrial goods is huge. The strategic industries that China is actively developing (e.g., national defense, aerospace, and automobile), as well as the construction of large stadiums and infrastructure required for Beijing Olympics, all require a large amount of mining and commodity materials, such as cement, concrete, steel bars, and rubbers. Crude oil is an important industrial material and it is also instrumental to transportation. Meanwhile, all the lighting equipments need to be powered by sources, such as hydro and coal fire.

Investment location. According to Model 2 in Table 4, the effects of the investments from Taiwan in Central or Western China are not significant $(\beta=-0.146, p>0.1)$. This result does not support H5. The frequency distribution of the research sample indicates that $16.5 \%$ of the top 1,000 Taiwanese companies in China in 2005 chose to invest in municipalities. The research findings suggest that the investments in municipalities yield better operating results. There are a total of four municipalities in China, i.e., Shanghai, Chongqing, Tianjin, and Beijing; all of these four metropolitans are known for easy-to-access transportation and geographic advantages. According to the list of top 1,000 Taiwanese enterprises in China from Commercial Times in 2005, four of the top 10 Taiwanese enterprises in China were located in these four municipalities. The remaining six of the top 10 were located in other parts of China. Therefore, it seems that Taiwanese 
investments in Chinese municipalities generate better management performances. This may be why the decisions to invest in Chinese municipalities lead to stronger operating results.

\section{Entry Modes and Management Performances}

According to Model 2 in Table 4, none of the methods, such as remittances from the third locations into China, via existing companies in the third locations and direct investments in China, report any significant influence $(\beta=-0.269, \beta=-0.013, \beta=-0.786$, and $\beta=0.085)$. This result does not support H6. This could be a result of certain legal restrictions or incentives for Taiwanese enterprises to invest in China. Out of the five entry modes defined by this paper, three of them are investments to China via third countries or territories, because this approach alleviates taxations in China and circumvents certain legal restrictions across the Taiwan Strait. Investments in China via the third locations either aim to alleviate tax burdens in China or circumvent regulations. As a matter of fact, as long as the funds can enter China, the entry mode does not affect the management performances of Taiwanese enterprises. This explains the research findings that none of the entry modes chosen has an impact on the management performances of Taiwanese enterprises.

\section{Conclusions and Management Implications}

\section{Conclusions}

The gradual liberalization and economic reforms in China over recent years have contributed to its strong economic growth. This, combined with the large pool of cheap labor, land, raw materials, and energy resources, has attracted many Taiwanese enterprises to set up manufacturing facilities in China since the 1990s. One cannot help but wonders why some Taiwanese enterprises survive and thrive but others perish in China. Hence, this paper samples the first half of the top 1,000 Taiwanese enterprises in China according to the 2012 survey by Commercial Times, hoping to identify the key success factors for Taiwanese enterprises in China. The research findings are as follows:

- The greater the investment is, the better the management performances of Taiwanese enterprises in China will be;

- The higher the ownership percentages is, the stronger the management performances of Taiwanese enterprises in China will be;

- The more recent the investments in China is, the better the management performances of Taiwanese enterprises in China will be;

- The investments in commodity, energy, and mining sectors in China yield the best management performances for Taiwanese enterprises.

\section{Management Implications}

This paper presents the following three management implications:

(1) Step-up in investment to achieve economies of size: Expansion is a natural course for Taiwanese enterprises active in China, because economies of size can reduce production costs and boost profitability. Extensive literature supports the view that the greater the organizational size is, the better the management performances will be. Taiwanese enterprises in the labor-intensive industries are advised to take advantage of the large pool of cheap labor by expanding size on a timely basis to enhance management performances;

(2) Timely investments in fledging industries in conjunction with industrial cycles in China: The majority of literatures confirm that organizational age is a positive factor to management performances. However, this 
paper finds an inverse correlation between organizational age and management performances of Taiwanese enterprises in China. In fact, the rapid economic development in China has been pacing up industrial cycles. Meanwhile, the improvement of human resources, the size of domestic demand, and the availability of cheap and abundant natural resources in China over recent years have made the commodity, energy, and mining sectors and IT, electronics, and machinery industries attractive targets for Taiwanese enterprises in China. The investments in these industries can easily access the large pool of cheap labour, raw materials, and energy resources and hence create lucrative profits;

(3) Ownership is critical to the management performances of Taiwanese enterprises investing in China: Taiwanese enterprises invested in China in the early days by joint venturing with local partners due to legal restrictions. It was difficult for Taiwanese parent companies to control the destiny of their Chinese subsidies due to the interference of local partners. In fact, the management performances were sometimes adversely affected due to conflicts in business strategies. Therefore, sole ownership presents a reliable investment strategy for Taiwanese enterprises in China. The $100 \%$ equity ownership of Chinese subsidiaries allows Taiwanese enterprises the flexibility in capital utilization and strategic implementations, and the ability to create strong management performances.

\section{References}

Banz, R. W. (1981). The relationship between return and market value of common ownerships. Journal of Financial Economics, 9(1), 3-18.

Beamish, P. W. (1993). The characteristics of joint ventures in the People's Republic of China. Journal of International Marketing, 1(2), 29-49.

Chang, S., \& Park, S. (2005). Types of firms generating network externalities and MNCs' co-location decisions. Strategic Management Journal, 26(7), 595-615.

Cochran, A. B. (1981). Small business mortality rates: A review of the literature. Journal of Small Business Management, 19(4), $50-59$.

Delios, A., \& Beamish, P. W. (1999). Geographic scope, product diversification, and the corporate performance of Japanese firms. Strategic Management Journal, 20(8), 711-727.

Dunning, J. H. (1988). Explaining international production. London: Irwin.

Gao, X. J. (1994). Determinants of profit investing in the mainland for foreign enterprises. Proceedings from Taiwan Economic Association Annual Meeting.

Hans, M., \& Tallman, S. (1997). Control and performance in international joint ventures. Organization Science, 8(3), $257-274$.

Jefferies, M. (2002). Critical success factors of the BOOT procurement system: Reflections from the stadium Australia case study. Engineering Construction and Architectural Management, 9(4), 352-361.

Kao, C. (1994a). Economic interaction between the two sides of the Taiwan Strait. In C. N. Wang (Ed.), Globalization, regionalization, and Taiwan's economy (pp. 141-170). Taipei: Chung-Hua Institution for Economic Research.

Kao, C. (1994b). Economic interdependence between Taiwan and mainland China, 1979-1992. In T. P. Lyons and V. Nee (Eds.), The economic transformation of South China (pp. 243-268). New York: Cornell East Asia Series.

Kao, C., \& Chen, W. R. (1998). The determinants of enter mode of ownership for Taiwanese firms investment in China mainland. Journal of Management, 15(3), 393-411.

Kao, C., \& Wu, S. Y. (1998). The impact of economic interaction between the two sides of the Taiwan Strait on Taiwan's economy. In Y. H. Yang (Ed.), Industrial development and policies in Taiwan (pp. 281-320). Taipei: Chung-Hua Institution for Economic Research.

Kogut, B. (1991). Joint ventures and the option to expand and acquire. Management Science, 37(1), 19-33.

Lawrence, S. T. (2004). Firm size, performance and CEO pay: Evidence from a group of American quality companies. Total Quality Management and Business Excellence, 15(1), 35-42.

Lin, Z. J., \& Lee, J. Z. (1997). China Taiwan factory to be factors in profit during the survival model of the application. In S. Yang (Ed.), The method and application of social science (pp. 185-209). Taipei: Research Center of Humanities and Social Sciences, Academia Sinica. 
Nachum, L., \& Wymbs, C. (2005). Product differentiation, external economies and MNE location choices: M\&As in global cities. Journal of International Business Studies, 36(4), 415-434.

Robbins, D. K., \& Pearce, J. A. (1992). Turnaround: Retrenchment and recovery. Strategic Management Journal, 13(4), $287-309$.

Schroath, F. W., Hu, M. Y., \& Chen, H. (1993). Country-of-origin effects of foreign investments in the People's Republic of China. Journal of International Business Studies, 24(2), 277-290.

Thompson, A., \& Strickland, A. J. (1998). Strategic management concept and cases. New York: McGraw Hill.

Vanhonacker, W. (1997). Entering China: An unconventional approach. Harvard Business Review, 75(2), 130-140.

Yan, L., Zhao, H., \& Baron, R. A. (2007). Influence of founder-CEOs' personal values on firm performance: Moderating effects of firm age and size. Journal of Management, 33(5), 673-696.

Yeung, I., \& Tung, R. (1996). Achieving business success in confusion societies: The importance of guanxi. Organization Dynamics, 25(2), 54-65.

Yigang, P., \& Peter, S. K. (1999). Financial performance and survival of multinational corporations in China. Strategic Management Journal, 20(4), 359-374.

Zhao, H., \& Zhu, G. (2000). Location factors and country-of-origin differences: An empirical analysis of FDI in China. Multinational Business Review, 8(1), 60-73.

Zhou, C., Delios, A., \& Yang, J. Y. (2002). Locational determinants of Japanese foreign direct investment in China. Asia Pacific Journal of Management, 19(1), 63-86. 